（東京大学工学部綜合試邪所：東宗都交京区）（昭和 27 年 7 月 9 日受理）

（72）発泡性防火染料の研究(第1報)

$\mathrm{NH}_{4} \mathrm{H}_{2} \mathrm{PO}_{4}-\left(\mathrm{NH}_{4}\right)_{2} \mathrm{CO}$-Paraformaldehyde-Starch 系整料について

\title{
梖井高景・泉富 雄
}

\section{1. 腥}

発泡性防火等料性乙独乙於て 1936 年以前に二，三のすのが央 用化されている(1)2。文樶近米国の ALBI Manuf. Co. より発 売されたすのは $\mathrm{NH}_{4} \mathrm{H}_{2} \mathrm{PO}_{4}-\left(\mathrm{NH}_{2}\right)_{2} \mathrm{CO}$-Paraformaldehyde-

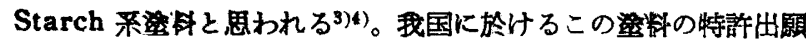

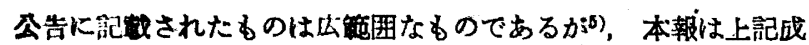
分よりなる释について配合制合と染膜形成能，起泡能力(後記) 及ひ防火性能との咸䋆を調へ，各战分の機能について得られた結 果を報告する。

\section{2. 原料}

$\left(\mathrm{NH}_{2}\right)_{2} \mathrm{CO}$ (U と略記) 及び $\mathrm{NH}_{4} \mathrm{H}_{2} \mathrm{PO}_{4}$ (NP と略記) (共に

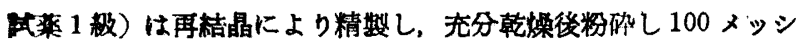
二通邀分を，Paraformaldehyde (F と略記) (化学用, H.CHO

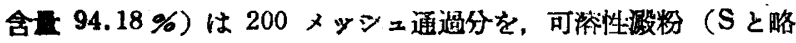
記）(化学用）は充分幹嬠し 100 メッシ二通過分を夫々使用した。
この場合普通の澱粉を赖用すると染脱玥成能が低下゙することが判 つたので，可涴性洀粉を使用した。

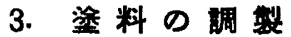

U, F, NP Zび S を混和した後，これに水を加え適当な稠度 とし $25^{\circ} \mathrm{C} ， 1$ 時閒故㽡したものを使用する。

\section{4. 粱膜の種別}

便宜上原料の配合組成で表わした。NP-S- $(U+F)$ の 3 成分柔 図で表わし，UとFとのモル比（U/F と略記）を悀々変更した。 この場合一部のUと F とは縮合し，尿素愷脂を形成することは勿 論である。

\section{[5. 膜形成能}

本報の如き㾞料では良好な染膜を形成するか否かが根本閒題な のでこれについて調べた。これより一杺料として使用し得る 組成が判る。造暚について硬さと，賃を観察した。硬さは結局強

第 1 因膜形成能
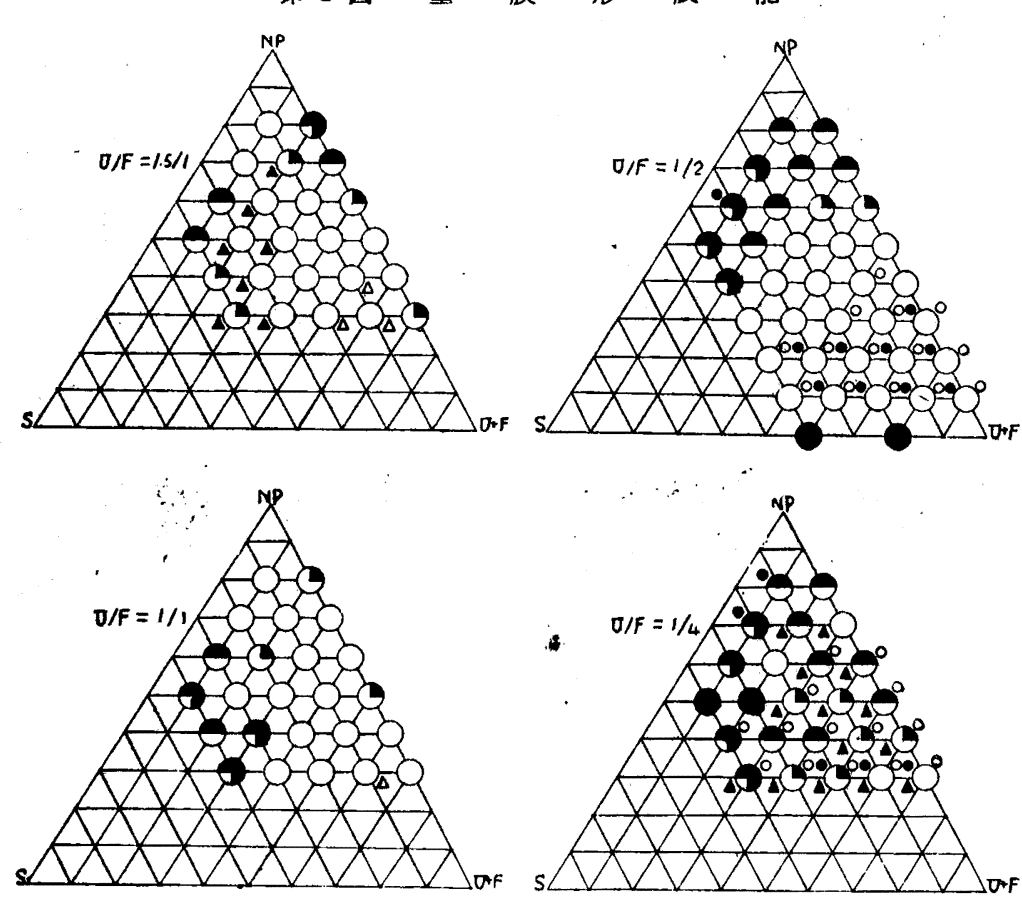

1) F. Kollemann, Technologie des Holzes 387 (1936).

2) D. R. P. 640,890 .

3) U. S. P. 2, 452, 054 .

4) A. J. Stamm, Ind. Eng. Chem. 41, 2150 (1949).

5) 日待出顆公告, 昭和 26-4031.

く爪きずをつける方法が䉍监でるあり，一忍の区別をつけられる ので次の如き記昂にて表わすことにした。
○：爪跡の殆どつかないもの
○：爪跡の嚾かにつくもの
○：爪跡がう強くこすると
○：爪跡がはつきりつくもの 削られるすの
: 膜形成能のないもの 

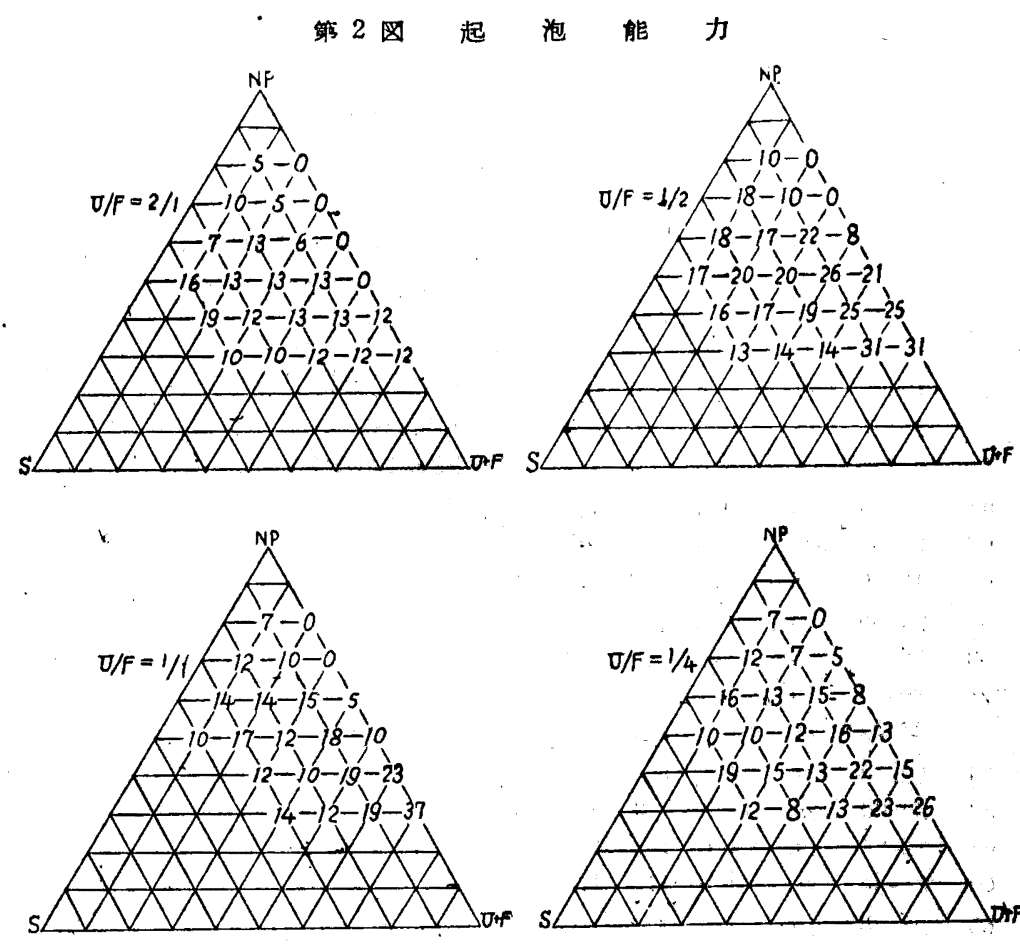

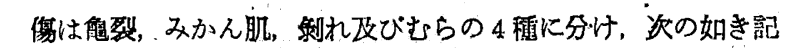
昂にて表わした。この系統の塗料は一般に白色不透明な染膜を与 えるのであるが，一部分が半透明の塗脱を与えるるのがある。こ の様なものを゙せら”と呼ぶことにした。
○.: 能
-：みかん肌
$\Delta$ : 剩れ
$\Delta$ : “む 5

原料 3 部に対し水 1 部を加え， $25^{\circ} \mathrm{C} ， 1$ 特間放置した 後 $5 \times 5$ $\times 0.5 \mathrm{~cm}$ 杉板に乾燥染膜の厚さが約 $0.5 \mathrm{~mm}$ になる様に湓布し， 約 5 カ月開空内に放路したものについて調ぺた。硬さは特に測定 直前 $25^{\circ} \mathrm{C}$ ，約 $75 \%$ R.H. に 2 日間放置したものにつき調べた。 この絬果を第 1 図に示す。

これより染膜形成能の太体の傾向が判る。U/F が 1/1 以外の ものは第が発生し易いが，1/1〜1/2 ならば大体よいことが判る。 NP の混入䇛囲は 80〜30\%，S は 30\% 以下でなければならな い。

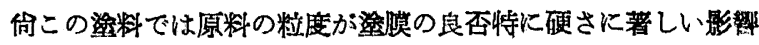
をむつことが判つた。しかし上記の原料の精度以下ならば差支え ない。

\section{6. 逢膜の起泡能力}

逢膜の加熱による起泡性能は次の如き予䚚的試崕により大体推 定されるの。料を乾燥重量として約 $0.2 \mathrm{~g}$ とり，これを $2 \times 2 \mathrm{~cm}$ に払げ䩐燥し，これを $500^{\circ} \mathrm{C} 2$ 分間加熱分解し，生成した海綿状

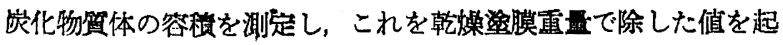
泡比容積 $(\mathrm{cc} / \mathrm{g})$ と呼び，迪泡能力を比較する値とした。起泡比 容積值は 3 個の平均をとるむのとした。この結果を第 2 図に示す。 但し起泡比容䠝值 $5 \mathrm{cc} / \mathrm{g}$ 以下のbのは便宜上 0 とした。

起泡比容䅪值は大体 $30 \mathrm{cc} / \mathrm{g}$ 以下であり, $10 \mathrm{cc} / \mathrm{g}$ 台のむのが 大部分である。U/F が $1 / 2$ のとき最も大で，2/1 或は $1 / 4$ のと

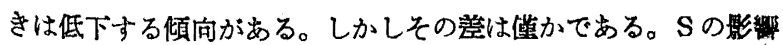
は NP が 80 50\% のときは S を混入すると起泡能力大となる

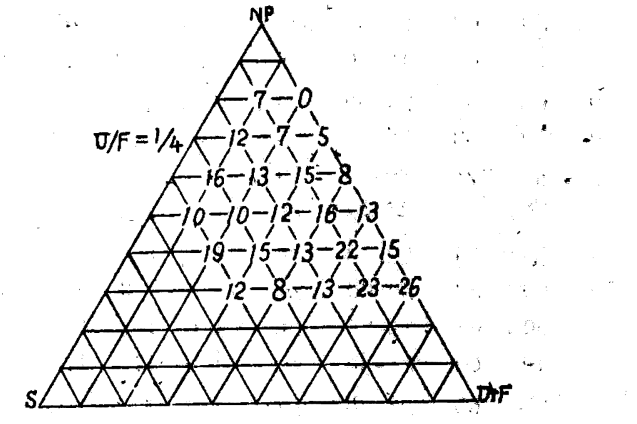

か，NP がそれ以下であるときは，かえつて低下せしめる域合が ある。

著者等は先に別種の祭料につき，この起泡能力試䀫と防火性能 試験 (後㲹) とを併行して行いこの閒の関係を調べたが, 起泡能 カのみでは防火性能を予測することは什来ないか，防火性能を支 配する重要なる因子であることを琹めだ)。

\section{7. 防火性能試匼}

防火性能試験は JIS-K 5661 の屋內用発泡性防火枒 の険 方法に淮じて行つた。防火性能はこの試験により圾験片の䤄温 度が $260^{\circ} \mathrm{C}$ に達寸る迄に要した時間（酎燃時間と呼ぶ）の長短に より比較するすのとした。 $24 \times 24 \times 0.5 \mathrm{~cm}$ 無䬦杉材に靯嬠淠膜

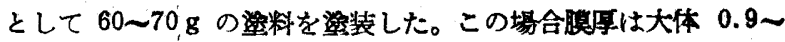
$1.0 \mathrm{~mm}$ 位であつた。約 3 力月閒室内に放置した後試検を行つ

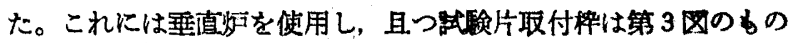
を用いた。JIS の堨合と異なり被加荆面は $15 \times 15 \mathrm{~cm}$ となつて いる。この結果を第 1 表に示す。

第 3 因试版取付枠

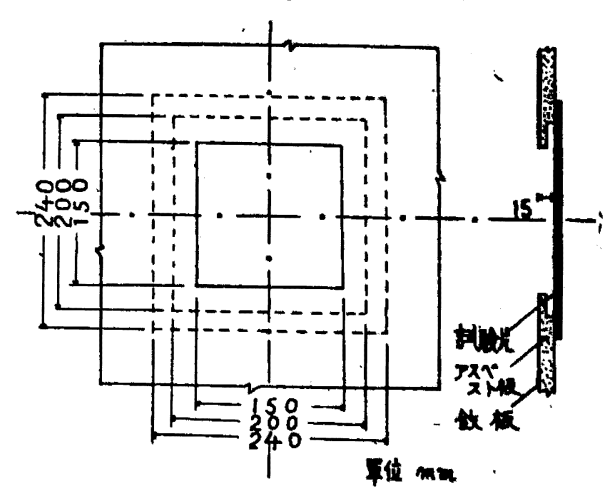

6) 桜井，泉，日本火災学会踰交菒 1，24 (1951)。 
第 1 表

\begin{tabular}{|c|c|c|c|c|c|c|c|c|c|c|}
\hline$\frac{U}{F}$ & $\begin{array}{l}\text { 試筑 } \\
\text { 片番 } \\
\text { 号 }\end{array}$ & $\begin{array}{l}\text { NP } \\
(\%)\end{array}$ & $\begin{array}{c}S \\
(\%)\end{array}$ & $\begin{array}{l}U+F \\
(\%)\end{array}$ & 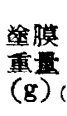 & & $\begin{array}{l}\text { 起泡比 } \\
\text { 容 穔 } \\
(\mathrm{cc} / \mathrm{g})\end{array}$ & 上発泡 & $\underbrace{(\mathrm{cm})}_{\text {中部 }}$ & 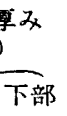 \\
\hline & L-135 & 70 & 0 & 30 & 61 & $17-00$ & 0 & 0 & 0.2 & 0.8 \\
\hline & 136 & "I & 10 & 20 & 70 & $18-30$ & 10 & 0 & 1.0 & $" 1$ \\
\hline & 137 & " & 20 & 10 & 72 & $23-00$ & 18 & 0.2 & 1.0 & "I \\
\hline & 138 & 60 & 0 & 40 & 60 & $15-40$ & 8 & 0.5 & 0.2 & 0 \\
\hline & 139 & "I & 10 & 30 & 63 & & 22 & 0.7 & 0.6 & 1.2 \\
\hline & 140 & "I & 20 & 20 & 68 & & 17 & 0.8 & 0.8 & 0.5 \\
\hline & 141 & " & 30 & 10 & 69 & & & 0.3 & 0.6 & 0.7 \\
\hline & 142 & 50 & 0 & 50 & 57 & $22-05$ & 21 & 0.5 & 0.8 & 1.5 \\
\hline & 143 & " & 10 & 40 & 64 & & & 0.3 & & 1.0 \\
\hline & 144 & "I & 20 & 30 & 63 & & 20 & 0.5 & & $" \prime$ \\
\hline & 145 & " & 30 & 20 & 69 & & & 0.4 & & 0.4 \\
\hline & 146 & 40 & 0 & 60 & 59 & 24-00 & 2 & 1.3 & 1. & 1.2 \\
\hline & 147 & " & 10. & 50 & 63 & & & 1.0 & & 1.1 \\
\hline & 148 & "I & 20 & 40 & 11 & & & $\prime \prime$ & & 0.9 \\
\hline & 149 & "I & 30 & 30 & 66 & & & 1.2 & & 1.2 \\
\hline & 150 & 30 & 0 & & 55 & & & 1.1 & & 1.2 \\
\hline & 151 & "I & 10 & 60 & 58 & 2 & & 1.5 & 1.4 & 0.9 \\
\hline & 152 & " & 20 & 50 & 62 & & 14 & 1.0 & 1.0 & 1.2 \\
\hline & 153 & "I & 30 & 40 & 66 & & & 1.6 & & 1.5 \\
\hline & 15 & 7 & 10 & 2 & 65 & & 1 & 0.2 & & 1.6 \\
\hline & 155 & 60 & 0 & 40 & 64 & & & 0.9 & 1.4 & 2.0 \\
\hline & 156 & $\prime \prime$ & 10 & 30 & 67 & 1 & 15 & 0.5 & 1.0 & 1.6 \\
\hline & 157 & $" \prime$ & 20. & 20 & 70 & 2 & & 0.6 & 1. & 11 \\
\hline & 158 & 50 & 10 & 40 & 69 & $24-35$ & 18 & 0.8 & 11 & 1.5 \\
\hline & 159 & $" \prime$ & 20 & 30 & 70 & $21-35$ & 12 & 0.5 & 0.7 & "I \\
\hline & 160 & 70 & 10 & 20 & 63 & & 7 & 0 & " & " \\
\hline & 161 & 60 & 0 & 40 & 60 & & & 0.4 & & 1.0 \\
\hline & 162 & $" 1$ & 10 & 30 & 61 & $17-10$ & 1 & 0 & 11 & 0.7 \\
\hline & 163 & "I & 20 & 20 & 62 & & & 0.3 & 0.8 & 1.0 \\
\hline & 164 & 50 & 10 & 40 & 53 & & & $" \prime$ & 0.6 & 0.6 \\
\hline & 165 & $" \prime$ & 20 & 30 & 58 & $18-38$ & 12 & $" \prime$ & 0.5 & "I \\
\hline & 16 & 70 & 10 & - & 65 & & & & & 1.7 \\
\hline & 167 & 60 & 0 & 40 & 67 & & 0 & 0.6 & 1.1 & 1.5 \\
\hline & 168 & $" \prime$ & 10 & 30 & 66 & $21-56$ & 6 & 0.2 & 0.8 & 1.3 \\
\hline & 169 & " & 20 & 20 & 59 & & 13 & 0.5 & 1. & 1.2 \\
\hline & 170 & 50 & 10 & 40 & 71 & $24-35$ & 11 & 1.5 & 1.7 & 1.7 \\
\hline & 171 & "/ & 20 & 30 & 67 & $20-40$ & " & 1.2 & 2.5 & \\
\hline
\end{tabular}

発泡層の酯みは防火性能試䀦を行つた試験片の発泡層の厚

考 みを云い，被加熱面の中心線上の上部中部下部の 3 筒所に 於て测定した。 $0.2 \mathrm{~cm}$ 以下のときは0と記した。

\section{8. 考察と総括}

8-1 防火性能と NP 含量 NP がこの系統の塗料火於て防火 性を附与せしめる第19因子であることは勿論であるが，NP 含 叠と防火性能とは比例的関係を示さないことは第 1 表より判る。 即ち防火性能は NP 含量のみをるつてしては予測されない。

8-2 防火性能と S含量 Sはこのもののみでは本貿的に防火 性能を附与する性能はない。しかしNP'と共存した場合, 発泡現 象に於て所謂㟶素供給体として有力な作用をもつ。Sを混入せし めた場合に防火性能が顕著に增大寸る場合すあるか，逆にかえつ て隇退する場合もある。NP 含量が 70 50\% の如き高い場合 $\mathrm{S}$ 含量 10 20\% 混入したとき良結果が䜅められる。

8-3 防火性能と $U+F$ 含量 Sの存在しない場合炕は U+F 含量の大なる程その起泡能力は大となり，且つ防火性能も增大寸 る。 Sの存在する時は概してU+F 含量の大なるときは $\mathrm{S}$ 含量炕 拘からずその防火性能は安定した值を示す。

8-4 防火性能と U/F U/F が 1/4 の如き Fが大なるときその 防火性能は劣化する。NP 含量 70 50\% の場合 $1 / 1$ が最むよい が 2/1 とは大差がない。1/2 はこれよりも多少劣る。U/F は 2/1 〜1/2 の範囲では余り影響がないと云える。

8-5 防火性能と起泡能力 起泡能力と防火性能は比例した関 保を示さない。しかし起泡比容積值が $10 \mathrm{cc} / \mathrm{g}$ 以下のものは一， 二の例外はあるが，その防火性能は小なるすのとして羑支交ない。 $10 \mathrm{cc} / \mathrm{g}$ 以上のものは起泡能力のみをるつてしては予測出来難い 結果を示す。このことは起泡能力試験によつては発泡啳組織の密 粗，試験中の発泡䁌の崩罗の難易が判らないし，又一面発泡性防 火塗料の防火性能は多くの因子炕より支配されることを暗示して いるるのであると哮ることが出来る。

（昭和 26 年 10 月 29 日，白化関東区東北支部大会諈演）

本研究の一部は文部省科学試騟砳究费によつて行つた。

本研究に当り御指尊を賜つた本学建筑科浜田教授に深甚の謝意

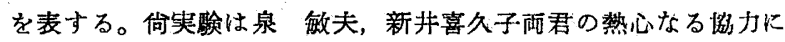
よつて行われたすのである。 